\title{
Project Scheduling Analysis Using the Precedence Diagram Method (PDM) Case Study: Surabaya's City Outer East Ring Road Construction Project (Segment 1)
}

\author{
Syahrur Romadhona*, Fredy Kurniawan, Julistyana Tistogondo \\ Department of Civil Engineering, Faculty of Engineering, Narotama University, Indonesia \\ *Corresponding author e-mail: syahrur_dpu@yahoo.com
}

Manuscript received 23 Feb 2021; revised 2 March. 2021; accepted 15 March 2021. Date of publication 2 April 2021

\begin{abstract}
The project acceleration by the Crash Program is one of the ways that is often used to make time and cost efficiency on an ongoing project. Acceleration of project completion time will affect the efficiency of equipment and labor productivity. In the case study of the Surabaya Outer East Ring Road Project Construction Segment 1, a project that has the potential to be accelerated is discussed in order to obtain efficiency values in terms of time and cost, Project acceleration by means of the Crash Program using the Precedence Diagram Method (PDM) method to determine the value of efficiency. This project uses resources, in this research the software used is Microsoft Project 2016. The research method used is to design network planning, find the critical path for each job, determine the work that has the potential to be accelerated, calculate the crash cost in additional working hours. and work shifts, calculating direct costs and indirect costs for each activity that changes due to changes in the duration of implementation, calculating the cost slope. Application of the Crash Program in the work of Asphalt Concrete Surface Layers (AC) thick $5 \mathrm{~cm}$ in the project will have an impact on increasing the time efficiency previously planned from 180 working days to 175 working days and efficiency with the difference in project costs of Rp. 18.313.935,8 with a ratio of 0,997 between the PDM method compared to the cost of the contract value calculated using the crashing project method.
\end{abstract}

Keywords: Project acceleration, efficiency, Precedence Diagram Method, Crash Program, Crashing.

\section{Introduction}

The purpose of Construction Management is to manage the implementation of a construction project so as to obtain optimal results in accordance with the requirements desired by the project owner, the requirements given are usually related to the implementation time, construction costs, and the quality of construction buildings, so intensive supervision and control must be carried out on time, cost and quality of construction, starting from the planning stage to the implementation stage [1].

A project has a certain period of time for completion. To get time and cost efficiency, the solution used is to accelerate the project completion time by means of the Crash Program. Crash Program is a method or mechanism in which the initial Time Schedule is neatly collided, resulting in shorter or faster project completion times. The crash program can be maximally applied if the network used allows a job to be done without waiting for the previous work to be completed $100 \%$ or what is commonly called overlapping [2]. In Construction Management, we know the PDM (Precedence Diagram Method) network which allows work to be done overlapping or a job can be started without having to wait for the previous work to be completed. Thus, optimization can be achieved in all aspects of time, cost and resources. Analysis on the Surabaya City Outer East Ring Road Construction Project (Segment 1) with a contract value of IDR 44,239,157,158.40 and the completion time agreed in the contract is 180 calendar days as an example of the application of the PDM method so that we can see the difference in costs and time that occurs after we apply it without any guarantee from the project [3].

By using the Precedence Diagram Method (PDM) to schedule projects, the age of a project will be known and what activities are included in the critical trajectory, so we will get a time duration comparison between the planned schedule and the schedule after scheduling using PDM. To get a cost comparison, it is necessary to carry out a calculation phase using a crash project after determining what activities can be accelerated in order to calculate labor efficiency by adding work hours (overtime) [4] [5]. 


\section{Literature Review}

\subsection{Project Definition}

Project activities can be interpreted as one of the temporary activities that take place in a limited period of time, with the allocation of certain resources intended to carry out tasks whose objectives have been clearly outlined. The task can be in the form of building factories, making new products or conducting research and development [6].

\subsection{Project Management}

Project management can be interpreted as the application of management functions in a project activity in other words it is an activity that regulates the course of activities in project implementation for all project stages [7].

\subsection{Network Diagram Method}

There are several types of network analysis methods that can be used in project time scheduling, including [8]:

1. Critical Path Method (CPM)

2. Precedence Diagramming Method (PDM)

3. Project Evaluation and Review Technique (PERT)

\subsection{PDM (Precedence Diagram Method)}

According to [9] the advantage of Precedence Diagram Method (PDM) compared to CPM is that PDM does not require fictitious / dummy activities so that network creation becomes simpler. This is because different overlapping relationships can be made without increasing the number of activities [10]. In PDM there are also known constraints. One constraint can only connect two nodes, because each node has two ends, namely the beginning or beginning $=(S)$ and the ending or finished $=(F)$. So here there are four types of constraints $[11]$, namely:

1. Constrain finishes to start - Finish to Start (FS)

This constraint provides an explanation of the relationship between the start of an activity and the completion of an earlier activity. Formulated as FS $(i-j)=$ a which means the activity (j) starts a day, after the activity that preceded it (i) is completed.

2. Constrain start to start - Start to Start (SS)

Provide an explanation of the relationship between the start of an activity with the start of an earlier activity. Or SS (i-j) = b which means an activity (j) starts after b days the previous activity (i) starts. Such constraints occur if before the previous activity is completed $100 \%$ then the activity (j) may start after a certain part of the activity (i) is finished.

3. Constrain finishes to finish - Finish to Finish (FF).

Provide an explanation of the relationship between the completion of an activity with the completion of the previous activity. Or FF $(i-j)=c$ which means an activity $(j)$ is completed after $\mathrm{c}$ days of the previous activity (i) are completed. This kind of constraint prevents the completion of an activity from reaching $100 \%$ before the previous activity has finished $(=\mathrm{c})$ days.

4. Constrain start to finish - Start to Finish (SF)

Explain the relationship between the completion of the activity and the start of the previous activity. Written by SF $(\mathrm{i}-\mathrm{j})=\mathrm{d}$, which means that an activity (j) is completed after d days of the previous activity (i) begin.

FFij

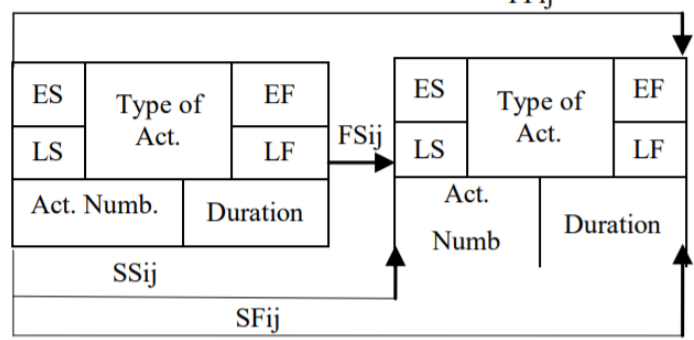

Fig 1. Relathionship I dan J (Source: Wulfram I. Ervianto)

\subsection{Calculation of Precedence Diagram Method (PDM)}

Activities in the Precedence Diagram Method (PDM) are described by a rectangular symbol because the location of the activity is in the node section, often called Activity On Node (AON). The activities in PDM are represented by an easily identifiable symbol, a common form that is often used is seen in Figure 2 PDM Node

\begin{tabular}{|l|l|l|}
\hline ES & \multirow{2}{*}{ TYPE OF } & EF \\
\cline { 1 - 1 } ACT & ACTIVITY & LF \\
\hline ACT. & \multicolumn{2}{|c|}{ DURATION } \\
NUMB. & \\
\hline
\end{tabular}

Fig 2. Node PDM 
Information:

$\mathrm{ES}=$ Earliest Start, the earliest start time of an activity.

$\mathrm{EF}=$ Earliest Finish, the earliest time to finish an activity. If there is only one previous activity, then the EF of a previous activity is the ES of the next activity.

LS = Latest Start, the last time an activity can start. That is, the final time the activity can start without slowing down the whole project.

$\mathrm{LF}=$ Latest Finish, the last time an activity can be finished.

The following formula for the calculation of PDM is :

1. Advanced calculation

a. Relationship activities from to end to finish

$\mathrm{EFj}=\mathrm{EFi}+\mathrm{FFi} \ldots .$.

$\mathrm{ESj}=\mathrm{EFj}-\mathrm{Dj}$

b. Relationship activities from to end to start

$\mathrm{ESj}=\mathrm{EFi}+\mathrm{FSij} \ldots \ldots . .$.

$\mathrm{EFj}=\mathrm{ESj}+\mathrm{Dj}$

c. Relationship activities from to start to start

$\mathrm{ESj}=\mathrm{ESi}+\mathrm{SSij} \ldots .$.

$\mathrm{EFj}=\mathrm{ESj}+\mathrm{Dj}$

d. Relationship activities from start to finish

$\mathrm{EFj}=\mathrm{ESi}+\mathrm{SFij} \ldots .$.

$\mathrm{ESj}=\mathrm{EFj}-\mathrm{Dj}$

2. Calculation backwards

a. Relationship activities from end to finish

$\mathrm{LFi}=\mathrm{LFj}-\mathrm{FFij}$

$\mathrm{LSi}=\mathrm{LFi}-\mathrm{On}$

b. Relationship activities from end to start

$\mathrm{LFi}=\mathrm{LSj}-\mathrm{FSij}$

$\mathrm{LSi}=\mathrm{LFi}-\mathrm{On}$

c. Relationship activities from start to start

$\mathrm{LSi}=\mathrm{LSj}-\mathrm{SSi}$

$\mathrm{LFi}=\mathrm{LSi}+\mathrm{Di}$

d. Relationship activities from start to finish

$\mathrm{LSi}=\mathrm{LFj}-\mathrm{SFij}$

$\mathrm{LFi}=\mathrm{LSi}+\mathrm{Di}$

3. An activity is said to be critical, if:

a. the earliest and most recent start time is $\mathrm{ES}=\mathrm{LS}$

b. the earliest and final finish time must be the same $\mathrm{EF}=\mathrm{LF}$

c. the duration of the activity is the same as the difference in the time of the last finish to the earliest start time LF - ES = D

d. Total float $=0=\mathrm{LF}-\mathrm{EF}=\mathrm{LS}-\mathrm{ES}$

\subsection{Metode Crashing}

Crashing Project is an action to reduce the overall duration of work after analyzing alternatives available from the network. Aims to optimize work time with the lowest cost. Often there are trade-offs in crashing, i.e. exchange of time and costs. This can be illustrated in the form of a time-cost graph (Figure 3).

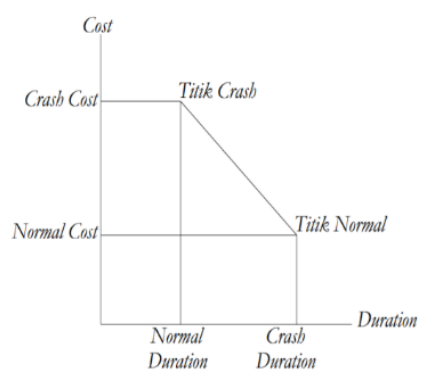

Fig 3. Relation Graph between Time and Cost in Normal Condition

In a crashing project, there are two time components, namely:

a. Normal Time, i.e. completion of activities under normal conditions,

b. Crash Time, which is the shortest time that is most likely to complete the activity. From these two components, we can get the Total Acceleration Time, with the equation:

Total Acceleration Time $=$ Normal Time - Acceleration Time

While the cost component in a crashing project is divided into three, namely:

a. Normal costs, which are direct costs to complete activities in normal conditions,

b. Crash Cost, which is the direct cost to complete an activity in the shortest time condition that is most likely to complete an activity. From these two components, we can get the Total Acceleration Cost, with the equation:

c. Total Acceleration Fees $=$ Acceleration Fees - Normal Costs

d. Acceleration Cost per Time Unit (Slope), i.e. direct costs to complete an activity in the shortest time condition in the smallest time unit specified, using the equation:

e. Acceleration Cost per Unit $($ Slope $)=$ Total Acceleration Cost $\div$ Total Acceleration Time 
To do a crash on a project, there are steps to complete it, namely:

a. Draw a network diagram for each event,

b. Calculate the total acceleration time, the total acceleration fee, and the acceleration cost per unit time for each event,

c. Determine the critical path and the length of the project,

d. Select the activity on the critical path that has a minimum acceleration rate, and reduce the time the activity is as much as possible

e. Update all time activities, if the desired time limit has been reached, then stop. If not, repeat step 3.

\subsection{Alternative Addition to Working Hours (Overtime)}

Crashing by adding work hours will affect the efficiency of the project. Productivity for these alternatives can be calculated using formulas. Daily Productivity

Productivity / hour $=$ Volume Normal Normal Duration

Productivity after crash

$=$ Daily Productivity $\div$ Normal Work Hours

$=$ Daily productivity $+($ Total Overtime Time $\times$ Productivity $/$ hour $\times \%)$

From the daily productivity value after the crash, the duration of the project completion can be sought after the acceleration (crash duration) Crash Duration $=$ Volume $\div$ Productivity after Crash

The amount of the crash cost can be calculated using the equation below.

Total Overtime Costs = Number of workers $\times(3$ hours $\times$ crashing $) \times$ overtime costs $/$ day

Crash Cost

$=$ Normal Direct Cost + Total Overtime Wage Fee

\section{Method}

The collection of data or information obtained from the relevant agencies, namely the contractor and the supervisor of the Surabaya,s City Outer East Ring Road Construction Project (Segment 1). There are two types of data needed for this research, first is primary data in the form of interviews with resource persons and direct observations in the field and the second is secondary data including $\mathrm{S}$ curve data and recapitulation of project cost calculations and variable cost data including the list of Budget Plans (RAB), list of material prices and wages as well as a daily report on the number of workers and Shop drawing. After the data from the project is collected, the first step that must be done in this research is to compile network planning, starting from determining the number of work activities, then determining the duration of each work, determining which activities precede, which activities follow and which activities can be carried out in the same time and put it in the Microsoft Project to find out the critical path of the work. After the network planning is arranged, the next step taken is to do Crashing analysis by determining the total acceleration time, the total acceleration cost and the total acceleration cost per unit time (cost slope), the calculation of the three is only done on the activities that are passed by the critical path. Activities that will be crashed are activities that have the longest duration and are allowed to be accelerated, after the crashing process, network planning is reorganized with the duration of the crashing (the latest duration).

\section{Results and Discussion}

Project data used in preparing new project scheduling consists of Workbreak Down Structure (WBS) data, project duration or Time Schedule curve $\mathrm{S}$, and work item analysis. These data are not directly used for scheduling new projects but are analyzed first so that they can be effectively applied to each method.

Table 1. Scheduling New Projects

\begin{tabular}{|c|c|c|c|}
\hline No & Activities & $\begin{array}{c}\text { Duration } \\
\text { (Date) }\end{array}$ & Predecessors \\
\hline 1 & Preparation and Site Office & 175 days & \\
\hline 2 & Project Signboard & 1,14 days & $2 \mathrm{SS}$ \\
\hline 3 & Preparation (Mobilisation \& Demobilisation) & 24 days & $2 \mathrm{SS}+6$ days \\
\hline 4 & Uitzet with waterPass / Theodolit & 8 days & $2 \mathrm{SS}$ \\
\hline 5 & Test Hole & 24 days & $2 \mathrm{SS}$ \\
\hline 6 & Safety sign + Warning Light & 175 days & 5 \\
\hline 7 & Production of Bouwplank & 8,8 days & $5 S S$ \\
\hline 8 & Project security fence, $\mathrm{H}=2$ meter & 12,8 days & $2 \mathrm{SS}$ \\
\hline 9 & Clean land area & 11,43 days & $2 \mathrm{SS}$ \\
\hline 10 & $\begin{array}{l}\text { Material mobilisation U-Ditch \& Cover U-Ditch } 200.200 .120 \text { from BTKD } \\
\text { Tambak Wedi to the Site }\end{array}$ & 10,78 days & 5 \\
\hline 11 & Excavation with Excavator & 16,3 days & 5 \\
\hline 12 & Land fill loader & 16,58 days & $13 \mathrm{SS}$ \\
\hline 13 & Sand & 3,02 days & $13 \mathrm{SS}$ \\
\hline 14 & Limestone heap With Heavy Equipment & 31,44 days & 5 \\
\hline 15 & Cover dam production h $2 \mathrm{~m}$; Th. $0,6 \mathrm{~m}$ & 80 days & 19SS \\
\hline 16 & $\begin{array}{l}\text { Rent a Steel Sheet pile SSP } h=12 \mathrm{~m}+\text { Braching (with erection and } \\
\text { recovation) }\end{array}$ & 80 days & 34 \\
\hline
\end{tabular}




\begin{tabular}{|c|c|c|c|}
\hline 17 & Dewatering & 80 days & $18 \mathrm{SS}$ \\
\hline 18 & Concrete demolition & 8 days & 19SS \\
\hline 19 & Bamboo pile dia. $10-12 \mathrm{~cm}$; long. $2 \mathrm{~m}$ & 24,97 days & $15 \mathrm{SS}$ \\
\hline 20 & Procure Mini Pile 30x30 fc 45 Mpa Fabrikasi & 17,04 days & 19SS \\
\hline 21 & Mini Pile Installation 30x30 fc 45 Mpa Fabrikasi & 19,2 days & $23 \mathrm{SS}+14$ days \\
\hline 22 & Demolition Pile Head & 12,43 days & $24 \mathrm{SS}+8$ days \\
\hline 23 & Continous Concrete Pile Cap Dim. 90 x 40 cm fc 30 Mpa (Steel $123 \mathrm{Kg}$ ) & 15,7 days & 25 \\
\hline 24 & Continous Concrete Pile Dim. 180 x 40 cm fc $30 \mathrm{Mpa}$ (Steel $112 \mathrm{Kg}$ ) & 13 days & 26SS \\
\hline 25 & Fabrication and Instalation Top-Bottom 400.300.120 fc 30 Mpa Precast & 14 days & $\begin{array}{l}61 \mathrm{SS}+2,29 \\
\text { days;26;27 }\end{array}$ \\
\hline 26 & Concrete Culvert B1 fc $30 \mathrm{Mpa}$ (Steel $235 \mathrm{Kg}$ ) & 12,2 days & 28 \\
\hline 27 & Stamp plate concrete $\mathrm{Tb} .35 \mathrm{~cm}$ fc $30 \mathrm{Mpa}($ Steel $92 \mathrm{Kg}$ ) & 13,6 days & $28 ; 29$ \\
\hline 28 & Pile Fabrication Type A1 Dia. $60 \mathrm{~cm}$ fc 52 Mpa Fabrikasi & 60 days & 3 \\
\hline 29 & Pile Fabrication Type C Dia. $60 \mathrm{~cm} \mathrm{fc} 52$ Mpa Fabrikasi & 50 days & 3 \\
\hline 30 & Pile Driving Installation Dia. $60 \mathrm{~cm} \mathrm{fc} 52 \mathrm{Mpa}$ Fabrikasi & 37,8 days & $\begin{array}{c}32 \mathrm{SS} ; 33 \mathrm{SS} ; 16 \\
\mathrm{SS}+14 \text { days }\end{array}$ \\
\hline 31 & Demolition Pile Head & 31,5 days & $34 \mathrm{SS}+8$ days \\
\hline 32 & Concrete pile reinforcement fc $35 \mathrm{Mpa}$ (Steel $524 \mathrm{Kg}$ ) & 24,2 days & 35SS \\
\hline 33 & Pile Head Type Ph0 fc 35 Mpa (Steel 181 Kg) & 13,9 days & $36 \mathrm{SS}$ \\
\hline 34 & Pile Head Type Ph1 fc 35 Mpa (Steel 137 Kg) & 11,2 days & $\begin{array}{c}36 \mathrm{SS}+3,43 \\
\text { days }\end{array}$ \\
\hline 35 & Pile Head Type (Pha, Pha) fc 35 Mpa (Steel 207 Kg) & 24 days & 38SS \\
\hline 36 & Pile Head Type (Phb, Phb) fc 35 Mpa (Steel 188 Kg) & 34,8 days & $\begin{array}{c}36 \mathrm{SS}+3,43 \\
\text { days }\end{array}$ \\
\hline 37 & Full Slab Anchor Instalation & 24,6 days & 40SS \\
\hline 38 & Fabrication and Installation Full Slab Precast fc 50 Mpa Type A & 1,8 days & $39 ; 40 ; 41$ \\
\hline 39 & Fabrication and Installation Full Slab Precast fc 50 Mpa Type B & 4,5 days & $41 ; 39 ; 40$ \\
\hline 40 & Fabrication and Installation Full Slab Precast fc 50 Mpa Type C & 1,8 days & $41 ; 39 ; 40$ \\
\hline 41 & Fabrication and Installation Full Slab Precast fc 50 Mpa Type A & 1,8 days & $42 ; 43 ; 44$ \\
\hline 42 & Fabrication and Installation Full Slab Precast fc 50 Mpa Type B & 4,5 days & $42 ; 43 ; 44$ \\
\hline 43 & Fabrication and Installation Full Slab Precast fc 50 Mpa Type C & 1,8 days & $42 ; 43 ; 44$ \\
\hline 44 & Fabrication and Installation Full Slab Precast fc 50 Mpa Type D & 13,3 days & $45 ; 46 ; 47$ \\
\hline 45 & Fabrication and Installation Full Slab Precast fc 50 Mpa Type E & 15,7 days & $45 ; 46 ; 47$ \\
\hline 46 & Fabrication and Installation Full Slab Precast fc 50 Mpa Type F & 13,3 days & $45 ; 46 ; 47$ \\
\hline 47 & Concrete Plate Tb. 50 cm fc 50 Mpa (Steel $309 \mathrm{Kg}$ ) & 7,6 days & 39SS \\
\hline 48 & Site mix Full Slab fc 50 Mpa (Steel $287 \mathrm{Kg}$ ) & 42,1 days & $51 \mathrm{SS}+8$ days \\
\hline 49 & Concrete Cip fc $50 \mathrm{Mpa}$ (Steel $320 \mathrm{Kg}$ ) & 37,3 days & 42SS \\
\hline 50 & Concrete fc $40 \mathrm{Mpa}$ (Full Slab Concrete filler) & 2,4 days & 53 \\
\hline 51 & Site Mix Concrete Barier Road fc $30 \mathrm{Mpa}$ (Steel $125 \mathrm{Kg}$ ) & 29,9 days & 56SS \\
\hline 52 & Concrete Barier Road Precast fc $30 \mathrm{Mpa}$ & 16,9 days & 54 \\
\hline 53 & Stamp plate concrete Th. $30 \mathrm{~cm} \mathrm{fc} 30 \mathrm{Mpa}$ (Steel $139 \mathrm{Kg}$ ) & 3,2 days & 52SS \\
\hline 54 & Elastomer Bearing Pad Full Slab Uk. 200x400x41 mm & 25,2 days & 37 \\
\hline 55 & Expansion Joint Full Slab (Type Asphaltic Plug) & 11,7 days & 70 \\
\hline 56 & Stone Foundation 1Pc: 4Ps & 51,2 days & 40 \\
\hline 57 & B0 Concrete Floor & 12,7 days & 13 \\
\hline 58 & U-Ditch Installation 200.200.120 fc 30 Mpa Precast & 34,2 days & 61 \\
\hline 59 & Cover U-Ditch Installation 200.200.120 fc 30 Mpa Precast & 8,6 days & 62 \\
\hline 60 & Fabrication and Instalation Cover Plat 120.23 .280 fc 30 Mpa Precast & 0,2 days & $63 \mathrm{FF}$ \\
\hline 61 & Solid Mixed stone & 8 days & 60 \\
\hline 62 & Garden land fill & 8 days & 65 \\
\hline
\end{tabular}




\begin{tabular}{|c|c|c|c|}
\hline 63 & Fabrication and Installation culvert dim. 30.20 .140 fc 20 Mpa Precast & 7,7 days & $66 \mathrm{FF}$ \\
\hline 64 & Instalation Kerb / Curbing type B dim. 20x30x50 ; fc $30 \mathrm{Mpa}$ & 9 days & $55 \mathrm{FF}$ \\
\hline 65 & $\begin{array}{l}\text { Concrete Culvert overtopping Th. } 10 \mathrm{~cm} \text { fc } 20 \text { Mpa with Wiremesh M8- } \\
150\end{array}$ & 14 days & $28 ; 29 ; 30$ \\
\hline 66 & Asphalt Concrete Surface Layers ( AC ) th. $5 \mathrm{~cm}$ & 23 days & 68 \\
\hline 67 & Thermoplastic road marking & 4 days & 59 \\
\hline 68 & U-Ditch fc 30 Mpa (Pemakaian Besi 113 Kg) & 4,51 days & $62 \mathrm{FF}$ \\
\hline 69 & Plant Rumput Gajah Mini & 10,1 days & $65 \mathrm{FF}$ \\
\hline 70 & Plant Tabebuya Trees min. Dia. $10 \mathrm{~cm}$ & 5,7 days & $65 \mathrm{FF}$ \\
\hline 71 & Cabel Installation NFGBY 4 X 10 mm & 27,43 days & $77 \mathrm{FF}$ \\
\hline 72 & Installation LED PJU Lamp ready to light & 27,43 days & $65 \mathrm{SS}$ \\
\hline 73 & Procure and Installation Lamp Panel PJU-1 Phase 5500 VA & 4 days & $76 \mathrm{FF}$ \\
\hline
\end{tabular}

\subsection{Critical Trajectory of Project Activities}

Project data used in preparing new project scheduling consists of Workbreak Down Structure (WBS) data, project duration or Time Schedule curve $S$, and work item analysis. These data are not directly used for scheduling new projects but are analyzed first so that they can be effectively applied to each method.

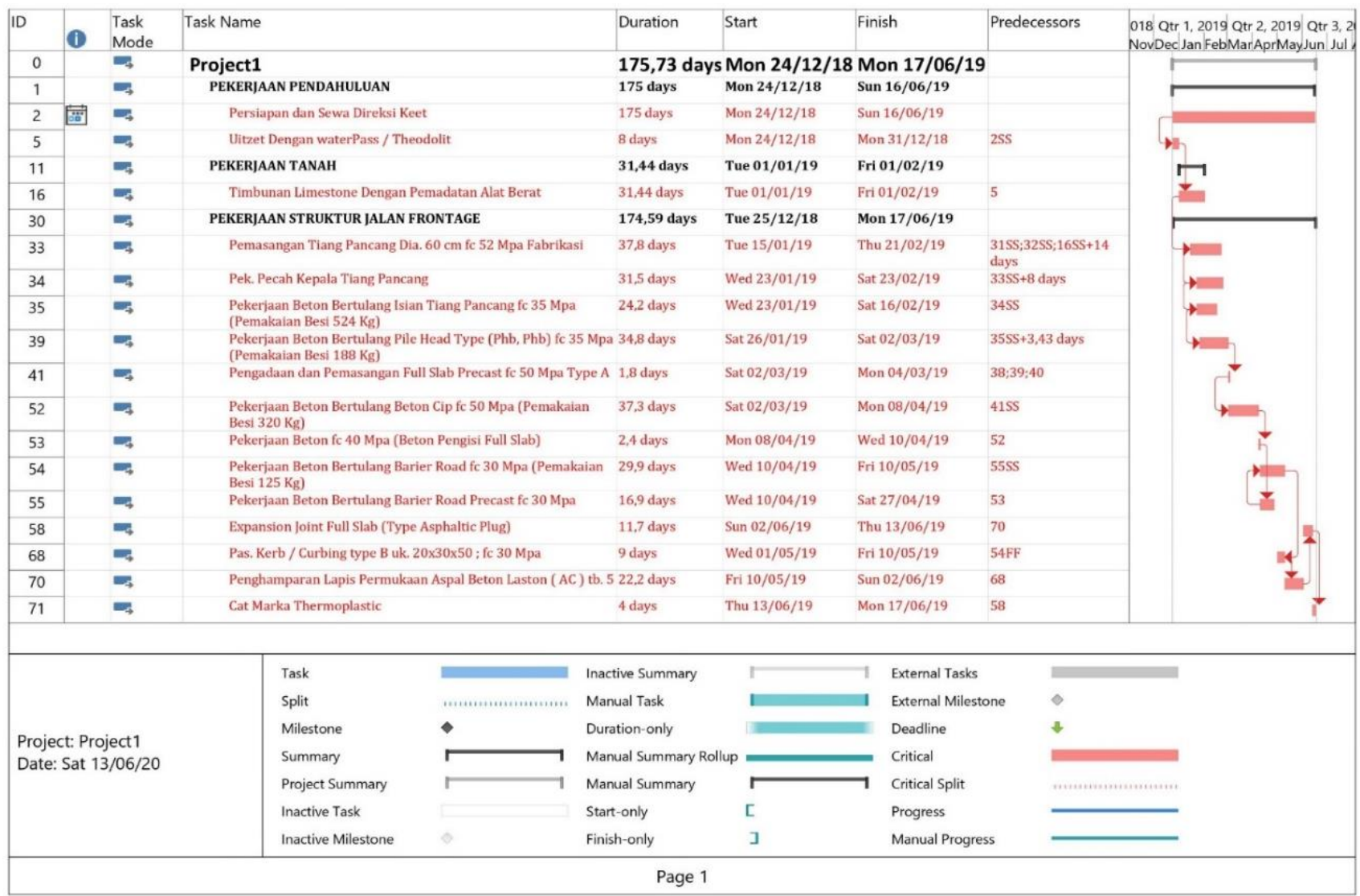

Fig 1. Activities that are in the Critical Path

After knowing the activities that are on the critical path, the next stage is to determine what work allows acceleration, namely work that has a long duration and can do overtime work. After calculating the coefficient of workers in the analysis as well as the volume of work, the work on the critical path that can be accelerated is the Asphalt Concrete Surface Layers (AC) thick $5 \mathrm{~cm}$ so that it can speed up the implementation time from 180 days to 175 days.

\subsection{Crash Project}

The calculation of the crash project or acceleration of the project is done by overtime work done by workers, so that it is closely related to the wages received by each worker. In this crash project, the activities carried out to accelerate the duration are activities that have a long duration and allow acceleration to be carried out on critical paths, namely the Asphalt Concrete Surface Layers (AC) tb. $5 \mathrm{~cm}$ with the initial work duration of 28 days. The project duration calculation uses the PDM approach, ie with a total project planning time of 180 days with a value of IDR 44.239.157.158,40. The crash project activity of Asphalt Concrete Surface Layers (AC) tb. $5 \mathrm{~cm}$ can be seen as follows: 


\subsection{Determine Project Indirect Costs}

To calculate the optimal cost with the acceleration duration of 5 working days, we must know the indirect and direct costs of the project. Costs for construction projects are known as Budget Plans (RAB) and Implementation Budget Plans (RAP). These RAB and RAP have differences, especially in the information provided from the two documents. In the RAB the information obtained is the cost required to complete each work item. While in the RAP the information obtained is the costs required for each project resource, namely material, labor, and equipment. Formulated the RAB and RAP in the construction project are as follows:

1. From the project data obtained a Cost Budget Plan (RAB). The actual project cost is in the form of an Implementation Budget (RAP), assuming that the contract value (RAB) includes the Contractor's profit and also a general overhead of $8,5 \%$. In mathematical form can be written as follows:

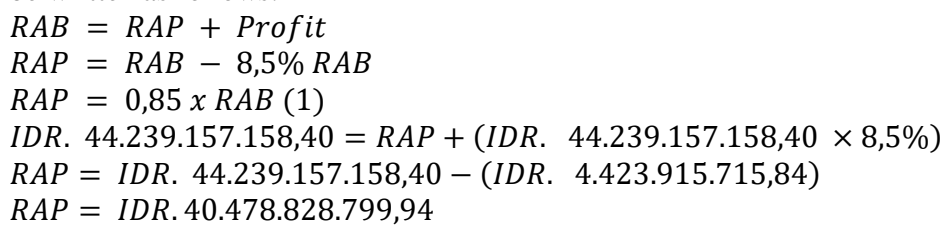

2. Actual cost project / RAP can be divided into:

a. Indirect costs / project overhead To simplify the calculation, assuming that the amount of indirect project costs is $1,5 \%$ of the RAB can be written

Indirect costs $=0.015 \times \mathrm{RAB}$

Indirect Costs $=0.015 \times$ IDR. 44.239.157.158,40

Indirect Costs $=$ IDR. 663.587.357,38

b. Direct costs represent the costs of implementing physical construction, the amount of which is the difference between the RAP and indirect costs, which can be calculated as follows:

Direct costs $=$ RAP - Indirect costs $=0,915 \times R A B-0,015 \times R A B$

$=0,9 \times R A B$

$=0,9 \times R p .44 .239 .157 .158,40$

$=I D R \cdot 39.815 .241 .442,56$

\section{Project Crash Calculation}

Known:

Asphalt activity weight (AC) Tb. $5 \mathrm{~cm}$

Overall project weight

$=$ IDR 1.170.122.294,40 (including 8,5\% profit and 1,5\% indirect costs)

$=$ IDR 44.251.588.408,40 (including 8,5\% profit and 1,5\% indirect costs)

Asphalt activity time (AC) Tb. $5 \mathrm{~cm}$

$=28$ days

Project activity time

$$
=180 \text { days }
$$

1. Reduction of Job Duration Per 1 Day (27 days)

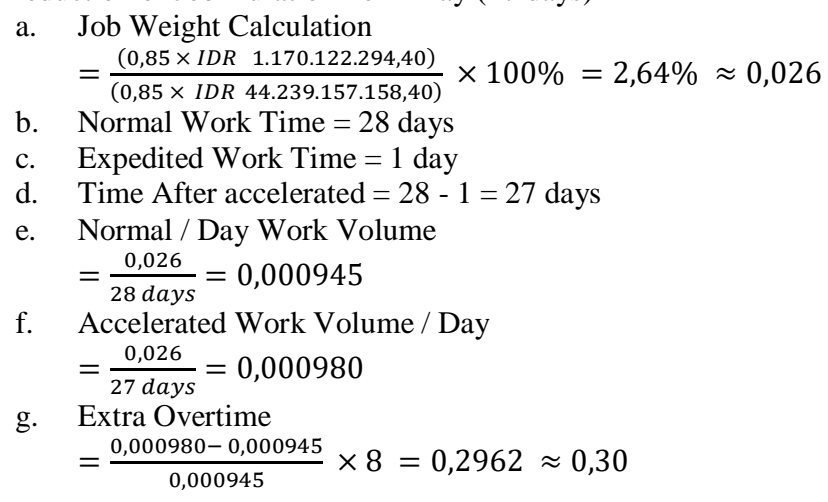

To calculate overtime work for Asphalt Concrete Surface Layers (AC) thick $5 \mathrm{~cm}$, then the worker's overtime / hour of work must be known.

Table 2. Analysis of the Price of Asphalt Concrete Surface Layers (AC) thick $5 \mathrm{~cm}$

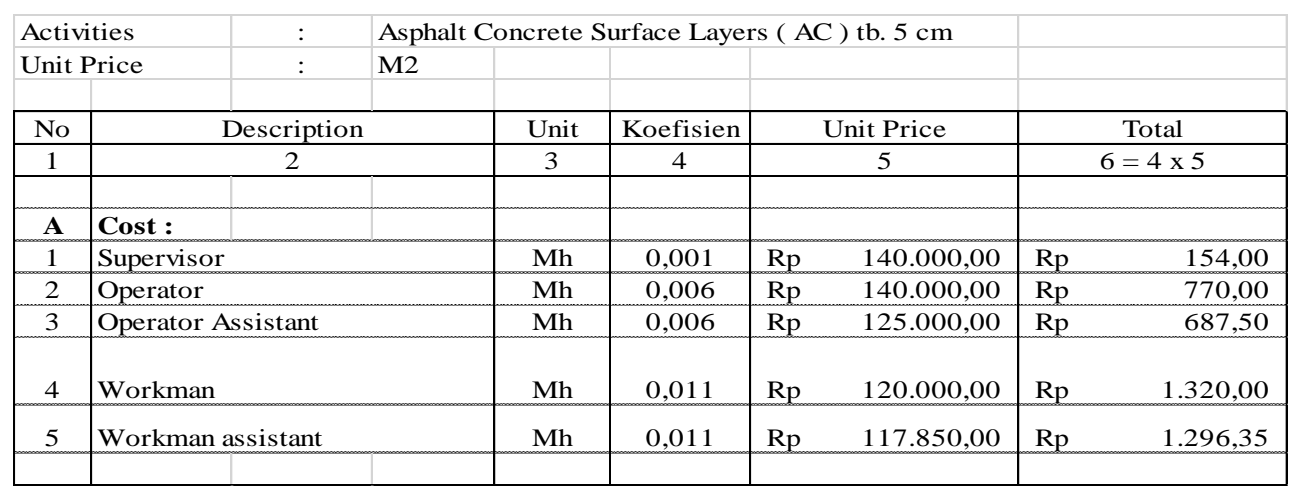


From the above table if it is assumed per day is 8 hours of work, then each hourly wage of each worker is as follows:

Tabel 3. Asphalt Concrete Surface Layers (AC) thick $5 \mathrm{~cm}$ Job Hourly

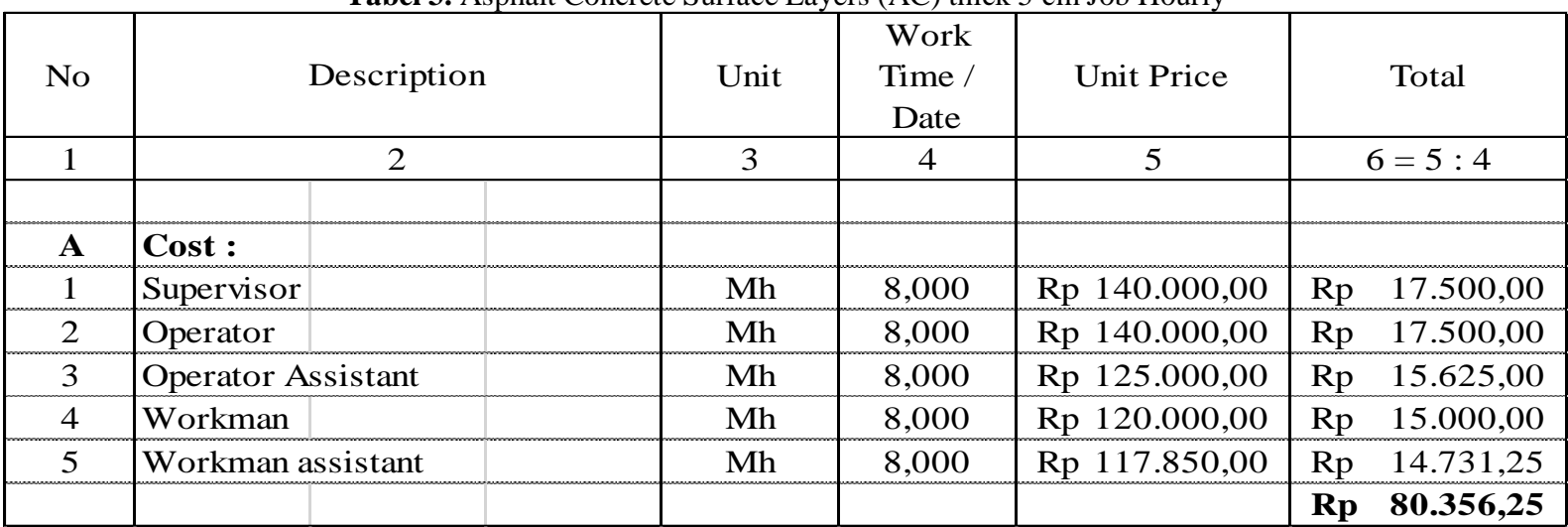

Because additional overtime is earned in less than 6 hours, the wages charged are overtime multiplied by the standard hourly cost, so that:

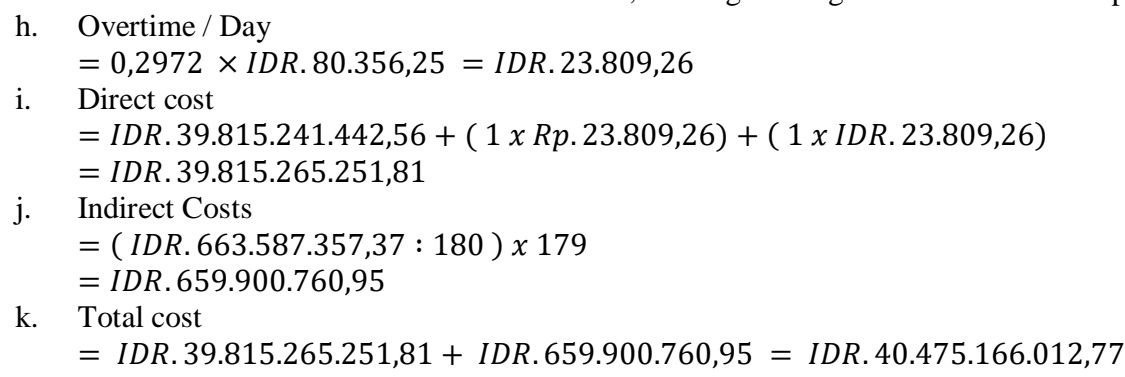

The following is a recapitulation of the crash project to obtain optimal costs.

Table 4. Crash Project Recapitulation

\begin{tabular}{|c|c|c|c|c|}
\hline $\begin{array}{c}\text { Crash Duration } \\
\text { (Day) }\end{array}$ & $\begin{array}{c}\text { Durasi } \\
\text { (Day) }\end{array}$ & $\begin{array}{c}\text { Direct Cost } \\
\text { (IDR) }\end{array}$ & $\begin{array}{c}\text { Indirect Cost } \\
\text { (IDR) }\end{array}$ & $\begin{array}{c}\text { Total Cost } \\
\text { (IDR) }\end{array}$ \\
\hline $\mathbf{a}$ & $\mathbf{b}$ & $\mathbf{c}$ & $\mathbf{d}$ & e = c + d \\
\hline 0 & 180 & $39.815 .241 .442,56$ & $663.587 .357,38$ & $40.478 .828 .799,94$ \\
\hline 1 & 179 & $39.815 .265 .251,82$ & $659.900 .760,95$ & $40.475 .166 .012,77$ \\
\hline 2 & 178 & $39.815 .289 .061,08$ & $656.214 .164,52$ & $40.471 .503 .225,59$ \\
\hline 3 & 177 & $39.815 .312 .870,34$ & $652.527 .568,09$ & $40.467 .840 .438,42$ \\
\hline 4 & 176 & $39.815 .336 .679,60$ & $648.840 .971,66$ & $40.464 .177 .651,25$ \\
\hline 5 & 175 & $39.815 .360 .488,86$ & $645.154 .375,23$ & $40.460 .514 .864,08$ \\
\hline
\end{tabular}

(Source: Data Processing, 2020)

The following shows a comparison of Scheduling Precedence Diagram Method and Schedule implementation plan to duration and cost.

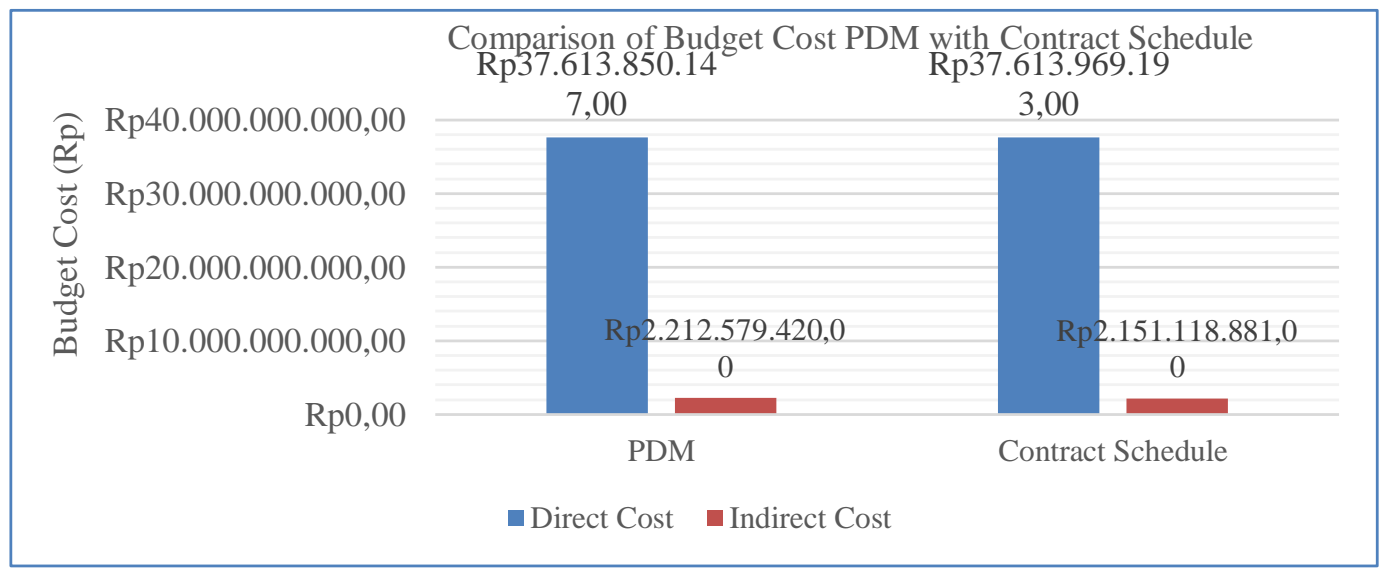

Fig 2. Comparison of scheduling to cost chart $(\mathrm{Rp})$ 


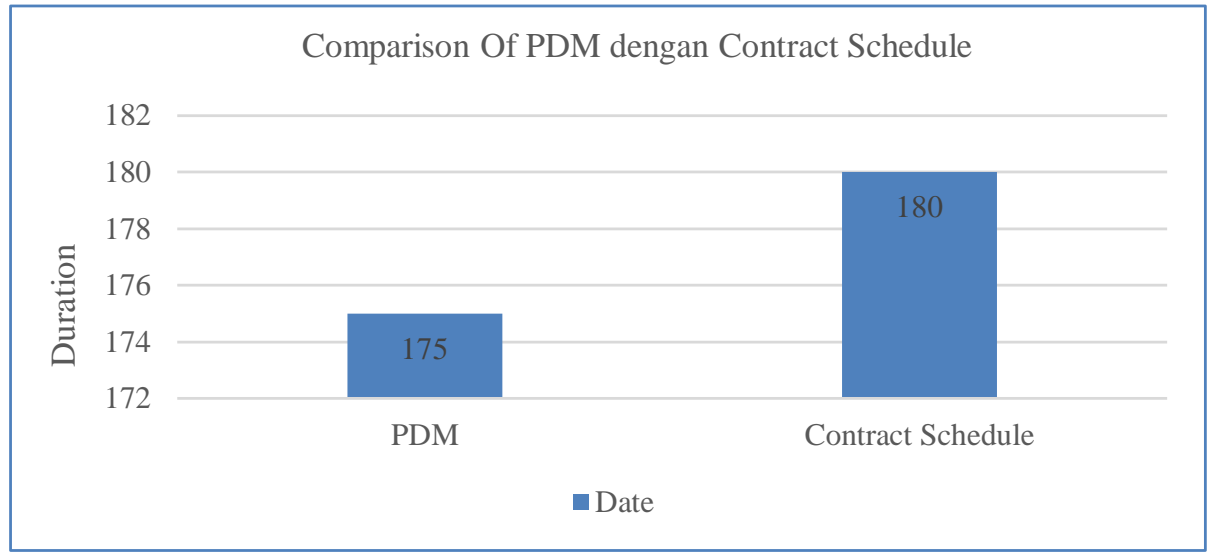

Fig 3. Comparison Chart Scheduling to Duration (Time)

\section{Conclusion}

1. The duration of the Plan is 180 calendar days according to the contract agreed upon with the value of:

Direct Cost = IDR. 39.815.214.442,56

Indirect Costs $\quad=$ IDR 663.587.357,38

Total Cost $=$ IDR 40.478.828.799,94

2. The duration after scheduling using the Precedence Diagram Method (PDM) is 175 days and the calculation of the crash project is obtained as follows:

Direct Cost $=$ IDR. 39.815.360.488,86

Indirect Costs $=$ IDR 654.154.375,23

Total Cost $\quad=$ IDR 40.460.514.864,08

Ratio analysis conducted on project costs by scheduling the Precedence Diagram Method and the Implementation Budget Plan (RAP) results in:

- The time difference in project implementation is 5 days

- The difference in Project Costs is IDR 18.313.935,85

Total Cost Rasio

$=\frac{I D R \cdot 40.460 \cdot 514 \cdot 864,08}{I D R \cdot 40.478 .828 .799,94}=\mathbf{0 , 0 9 7}$

Cost Ratio $=\frac{X}{y}<1$

Where, $x=$ the cost of the Precedence Diagram Method $\mathrm{y}=$ cost of Implementing Initial Schedule

If $=\frac{X}{y}<1$, then the project implementation using PDM scheduling will be more profitable.

Based on the results of the above analysis, it can be seen that acceleration using the PDM method by using the help of Microsoft Project software to identify critical paths can reduce the time of execution of work to 175 days of efficiency which is calculated based on the ratio of Crash Project cost comparisons using PDM with RAP costs less than 1 which can it was concluded that the implementation using the PDM method was more profitable.

\section{References}

[1] I. P. Setiadi and A. Andi, "MONITORING DAN ANALISIS JADWAL PROYEK MENGGUNAKAN METODE PERFORMANCE INTENSITY DAN CPM PADA PROYEK HOTEL,” Dimens. Utama Tek. Sipil, vol. 5, no. 2, 2018, doi: 10.9744/duts.5.2.17-25.

[2] M. N. Ihwanudin, "ANALISA PENJADWALAN PROYEK PIPA CARBON DENGAN METODE FUZZY LOGIC APPLICATION FOR SCHEDULING," Stat. F. Theor, vol. 53, no. 9, 2017.

[3] N. M.T., "ANALISA BIAYA DAN PENJADWALAN PADA PROYEK PENATAAN BANGUNAN KAWASAN STRATEGIS MASJID RAYA SUMBAR KOTA PADANG,” Rang Tek. J., vol. 1, no. 2, 2018, doi: 10.31869/rtj.v1i2.769.

[4] I. T. Derka, H. Suyoso, and A. Ratnaningsih, "A SCHEDULING ON IMPLEMENTATION OF ISDB PROJECT JEMBER UNIVERSITY WITH PRECEDENCE DIAGRAM METHOD,” J. Rekayasa Sipil dan Lingkung., vol. 3, no. 2, 2019, doi: 10.19184/jrsl.v3i2.11089.

[5] "Determination of Critical Pattern of 60 Meter Ship Construction Project Using Precedence Diagram Method (PDM)," Int. J. Syst. Appl. Eng. Dev., vol. 14, 2020, doi: 10.46300/91015.2020.14.14.

[6] I. Soeharto, "Manajemen proyek (Dari konseptual sampai operasional)," J. Korean Phys. Soc., vol. 60, no. 5, 2012.

[7] I. Soeharto, "Manajemen Proyek Jilid 1 (Dari Konseptual sampai Operasional)," in Manajemen Proyek Jilid 1 (Dari Konseptual sampai Operasional), vol. 60, no. 5, 1999.

[8] I. A. Permatasari and J. H. Wijaya, "THE COMPARISON OF FOOD POLICY ERA THE LEADERSHIP OF SOEHARTO AND SUSILO BAMBANG YUDHOYONO,” J. Kebijak. Pembang. Drh., vol. 2, no. 1, 2018, doi: 10.37950/jkpd.v2i1.35.

[9] W. Ervianto, "Manajemen Proyek Konstruksi-Edisi Revisi," Manaj. Proy. Konstr. Revisi, 2006.

[10] W. I. Ervianto, “Tantangan Pembangunan Infrastruktur dalam Proyek Strategis Nasional Indonesia," Simp. II UNIID 2017, vol. 2, no. $1,2017$.

[11] Ir. Iman Soeharto, "Manajemen Proyek Jilid 1 (Dari Konseptual sampai Operasional)," Manaj. Proy. Jilid 1 (Dari Konseptual sampai Oper., vol. 60, no. 5, 1999, doi: 10.3938/jkps.60.674. 